\title{
KEPASTIAN HUKUM KONTRAK KARYA P.T. FREEPORT INDONESIA DALAM PERSPEKTIF ASAS HAK MENGUASAI NEGARA
}

\author{
Tengku Erwinsyahbana \\ Vivi Lia Falini Tanjung \\ Program Magister Kenotariatan \\ Universitas Muhammadiyah Sumatera Utara \\ E-mail: erwin6768@gmail.com
}

\begin{abstract}
Abstrak
Kontrak karya penambangan emas di Kabupaten Mimika (Papua) ditandatangani oleh Pemerintah Indonesia dengan P.T. Freeport Indonesia di tahun 1967, berarti Pemerintah Indonesia berkedudukan sebagai salah satu pihak dalam kontrak tersebut. Persoalan yuridis yang perlu diperhatikan terkait dengan peran Pemerintah Indonesia (badan hukum publik) yang berkedudukan sebagai salah satu pihak, dalam hubungannya dengan asas hak menguasai negara. Kenyataan seperti ini menarik untuk diteliti dan dianalisis, yang jenis penelitiannya adalah yuridis normatif dengan pendekatan perundang-undangan dan pendekatan asas. Penelitian ini bersifat deskriptif, dan data penelitian berupa data sekunder, sehingga metode pengumpulan data dilakukan dengan teknik studi dokumen, sedangkan analisisnya dilakukan secara yuridis kualitatif. Berdasarkan hasil penelitian dapat diketahui bahwa konsep yuridis dikuasai oleh negara tidak berarti negara sendiri menjadi pengusaha, usahawan atau ordernemer, dan lebih tepat dikatakan bahwa kekuasaan negara terdapat pada membuat peraturan guna kelancaran jalan ekonomi, dan jika diperhatikan kontrak karya antara Pemerintah dengan P.T. Freeport Indonesia, terlihat bahwa Pemerintah Indonesia sebagai organ Negara telah bertindak menjadi pengusaha, sehingga dapat dikatakan kontrak karya ini telah bertentangan dengan asas-asas yang terdapat Pancasila dan UUD 1945, serta bertentangan dengan ajaran (doktrin) tentang kepastian hukum.
\end{abstract}

Kata Kunci: Freeport, Hak Menguasai Negara, Kontrak Karya.

\section{A. Latar Belakang Masalah}

Sebagai negara hukum, maka di Indonesia hukum harus dapat menjamin adanya kepastian hukum dalam semua aspek kehidupan, yang muaranya adalah untuk mewujudkan keadilan dan kemakmuran bagi kehidupan masyarakat Indonesia. Keadilan dan kemakmuran harus tercermin pada semua aspek kehidupan, maksudnya bahwa semua rakyat mempunyai kesempatan yang sama dalam meningkatkan taraf kehidupan; memperoleh lapangan pekerjaan; men- 
dapatkan pelayanan sosial, pendidikan dan kesehatan; mengemukakan pendapat; melaksanakan hak politik; mengamankan dan mempertahankan negara; serta mendapatkan perlindungan dan kesamaan di depan hukum. Dengan demikian, bangsa adil berarti tidak ada diskriminasi dalam bentuk apapun, baik antar individu, gender, maupun wilayah. ${ }^{1}$ Keadilan dan kemakmuran ini harus diwujudkan oleh negara, karena dalam Alinea Keempat Pembukaan Undang Undang Dasar Tahun 1945 (UUD 1945), telah diamanatkan bahwa salah satu tujuan Negara Republik Indonesia adalah untuk memajukan kesejahteraan umum.

Terkait dengan tujuan negara sebagaimana tersebut di atas, maka dalam Batang Tubuh UUD 1945, yaitu pada Pasal 33 ayat (3), ditentukan bahwa bumi dan air, dan kekayaan alam yang terkandung di dalamnya dikuasai oleh negara dan dipergunakan untuk sebesar-besar kemakmuran rakyat. Ketentuan ini dapat dimaknai bahwa sebenarnya kekayaan-kekayaan yang terdapat dari sumber daya alam di Indonesia, tidak boleh dikuasai oleh individu, terlebih lagi oleh warga atau perusahaan asing.

Mengingat sumber kekayaan alam yang tersedia, maka untuk pengelolaannya pada tahun 1967 telah diterbitkan Undang-undang Nomor 11 Tahun 1967 tentang Ketentuan-ketentuan Pokok Pertambangan, yang kemudian digantikan dengan Undang-undang Nomor 4 Tahun 2009 tentang Pertambangan Mineral dan Batubara (UU No. 4 Tahun 2009). Dalam konsideran UU No. 4 Tahun 2009, disebutkan bahwa mineral dan batubara yang terkandung dalam wilayah hukum pertambangan Indonesia merupakan kekayaan alam tak terbarukan sebagai karunia Tuhan Yang Maha Esa yang mempunyai peranan penting dalam memenuhi hajat hidup orang banyak, karena itu pengelolaannya harus dikuasai oleh negara untuk memberi nilai tambah secara nyata bagi perekonomian nasional dalam usaha mencapai kemakmuran dan kesejahteraan rakyat secara berkeadilan.

Diberlakukannya UU No. 4 Tahun 2009, karena dengan pertimbangan perkembangan nasional maupun internasional, bahwa UU No. 11 Tahun 1967 sudah tidak sesuai lagi, sehingga dibutuhkan perubahan peraturan perundang-

1 Lampiran Undang-undang Nomor 17 Tahun 2007 tentang Rencana Pembangunan Jangka Panjang Nasional Tahun 2005-2025. 
undangan di bidang pertambangan mineral dan batubara yang dapat mengelola dan mengusahakan potensi mineral dan batubara secara mandiri, andal, transparan, berdaya saing, efisien, dan berwawasan lingkungan, guna menjamin pembangunan nasional secara berkelanjutan. ${ }^{2}$ Hal ini menunjukkan arti bahwa pengelolaan kekayaan alam Indonesia sudah seharusnya dilaksanakan secara mandiri oleh bangsa Indonesia (perusahaan dan modal Indonesia), tanpa mengandalkan pihak asing (perusahaan dan modal asing). Bahkan dalam Pasal 2 UU No. 4 Tahun 2009, ditentukan pula bahwa pertambangan mineral dan/atau batubara dikelola berasaskan: (1) manfaat, keadilan, dan keseimbangan; (2) keberpihakan kepada kepentingan bangsa; (3) partisipatif, transparansi, dan akuntabilitas; serta (4) berkelanjutan dan berwawasan lingkungan.

Salah satu tujuan pengelolaan mineral dan batubara adalah untuk mendukung dan menumbuhkembangkan kemampuan nasional agar lebih mampu bersaing di tingkat nasional, regional, dan internasional, ${ }^{3}$ oleh sebab itu mineral dan batubara sebagai sumber daya alam yang tak terbarukan merupakan kekayaan nasional yang dikuasai oleh negara untuk sebesar-besar kesejahteraan rakyat, harus diselenggarakan oleh pemerintah dan/atau pemerintah daerah, ${ }^{4}$ tetapi dalam faktanya sebagian terbesar kekayaan alam Indonesia justru tidak kelola oleh pemerintah dan/atau pemerintah daerah, melainkan oleh orang asing. Sebagai contoh adalah tambang emas di Kabupaten Mimika (Papua), yang dikelola oleh P.T. Freeport Indonesia melalui suatu perjanjian dengan Pemerintah Indonesia, yang dinamakan "kontrak karya".

Kontrak karya penambangan emas di Kabupaten Mimika (Papua ) yang ditandatangani oleh Pemerintah Indonesia dengan P.T. Freeport Indonesia di tahun 1967, didasarkan pada Undang-undang Nomor 1 Tahun 1967 tentang Penanaman Modal Asing dan Undang-undang Nomor 11 Tahun 1967 tentang Ketentuan-ketentuan Pokok Pertambangan. Hal ini berarti bahwa Pemerintah

\footnotetext{
${ }^{2}$ Lihat konsideran Undang-undang Nomor 4 Tahun 2009 tentang Pertambangan Mineral dan Batubara

${ }^{3}$ Pasal 3 Undang-undang Nomor 4 Tahun 2009 tentang Pertambangan Mineral dan Batubara.

4 Pasal 4 ayat (1) dan ayat (2) Undang-undang Nomor 4 Tahun 2009 tentang Pertambangan Mineral dan Batubara.
} 
Indonesia berkedudukan sebagai salah satu pihak (badan hukum publik) dalam kontrak karya tersebut, dan P.T. Freeport Indonesia sebagai pihak (badan hukum privat) lainnya. Persoalan yuridis yang perlu diperhatikan adalah terkait dengan peran Pemerintah Indonesia (badan hukum publik) yang berkedudukan (berposisi) sebagai salah satu pihak pada kontrak karya tersebut dalam hubungannya dengan asas hak menguasai negara, dan oleh sebab itu perlu dianalisis melalui penelitian yang berjudul: "Kepastian Hukum Kontrak Karya P.T. Freeport Indonesia dalam Perspektif Asas Hak Menguasai Negara”.

\section{B. Metode Penelitian}

Dilihat dari jenisnya, maka penelitian hukum dapat dibedakan menjadi penelitian hukum normatif dan penelitian hukum empiris, ${ }^{5}$ sedangkan penelitian hukum normatif adalah penelitian terhadap bahan kepustakaan (data sekunder) yang relevan dengan permasalahan yang akan dianalisis, baik berupa bahan hukum primer, bahan hukum sekunder maupun bahan hukum tertier. ${ }^{6}$ Mengingat bahwa data penelitian ini lebih difokuskan pada data sekunder, maka jenis penelitian ini adalah penelitian hukum normatif.

Terkait dengan penelitian normatif, maka ada beberapa pendekatan yang dapat digunakan, yaitu: (1) pendekatan perundang-undangan; (2) pendekatan konsep; (3) pendekatan analitis; (3) pendekatan perbandingan; (5) pendekatan historis; (6) pendekatan filsafat; dan (7) pendekatan kasus. ${ }^{7}$ Penelitian hukum normatif dengan pendekatan perundang-undangan, berarti fokus penelitiannya adalah terhadap berbagai aturan hukum sebagai tema sentralnya, ${ }^{8}$ dan berhubung penelitian ini difokuskan untuk mengkaji/menganalisis aturan hukum (peraturan perundang-undangan) yang terkait dengan kontrak karya dalam pelaksanaan eksploitasi tambang emas di Kabupaten Mimika (Papua), maka pendekatan

${ }^{5}$ Soerjono Soekanto. 2012. Pengantar Penelitian Hukum. Cetakan Ketiga. Jakarta: UIPress. Hlm. 51.

${ }^{6}$ Soerjono Soekanto dan Sri Mamudji. Penelitian Hukum Normatif, Suatu Tinjauan Singkat. Cetakan Keenam. Jakarta: RadaGrafindo Persada. 2003. Hlm. 14.

7 Johnny Ibrahim. 2006. Teori dan Metodologi Penelitian Hukum Normatif. Cetakan Kedua. Malang: Bayumedia Publishing. Hlm. 300.

${ }^{8}$ Ibid. Hlm. 302. 
penelitian yang digunakan adalah pendekatan perundang-undangan. Selain itu, menurut Soerjono Soekanto dikatakan bahwa pendekatan hukum normatif dapat pula mencakup: (1) penelitian terhadap asas-asas hukum; (2) penelitian terhadap sistematika hukum; (3) penelitian terhadap taraf sinkronisasi hukum; (4) penelitian sejarah hukum; dan (4) penelitian perbandingan hukum, ${ }^{9}$ dan berhubung penelitian ini dimaksudkan untuk menganalisis posisi (kedudukan) Pemerintah Indonesia dalam kontrak karya dikaitkan dengan asas hak menguasai Negara, maka pendekatan yang juga digunakan adalah pendekatan terhadap asasasas hukum.

Data penelitian ini adalah data sekunder yang bersumber dari bahan hukum primer, bahan sekunder dan bahan tertier. Bahan hukum primer penelitian ini antara lain: Undang Undang Dasar 1945, Undang-undang Nomor 1 Tahun 1967 tentang Penanaman Modal Asing sebagaimana telah dicabut dengan Undang Undang Nomor 25 Tahun 2007 tentang Penanaman Modal, serta dan Undangundang Nomor 11 Tahun 1967 tentang Ketentuan-ketentuan Pokok Pertambangan sebagaimana telah dicabut dengan Undang-undang Nomor 4 Tahun 2009 tentang Pertambangan Mineral dan Batubara. Bahan hukum sekunder berupa buku ataupun laporan penelitian dan jurnal yang memberikan penjelasan terhadap bahan hukum primer, sedangkan bahan hukum tertier adalah bahan yang menjelaskan bahan hukum sekunder yang diperoleh dari kamus dan internet.

Alat pengumpul data dalam penelitian hukum lazimnya menggunakan studi dokumen, pengamatan atau observasi, dan wawancara. Ketiga jenis alat pengumpul data ini dapat dipergunakan masing-masing, maupun secara bergabung untuk mendapatkan hasil semaksimal mungkin, ${ }^{10}$ tetapi penelitian ini hanya menggunakan metode studi dokumen.

Analisis data dapat digolongkan menjadi 2 (dua) macam, yang meliputi analisis kuantitatif dan analisis kualitatif. Analisis kualitatif merupakan analisis data yang tidak menggunakan angka, melainkan memberikan gambaran-gambaran (deskripsi) dengan kata atas temuan-temuan, dan oleh karena itu lebih meng-

\footnotetext{
${ }^{9}$ Soerjono Soekanto, Op. Cit. Hlm. 51.

${ }^{10}$ Ibid. Hlm. 66.
} 
utamakan mutu (kualitas) dari data, bukan kuantitas, dan dalam penelitian hukum normatif analisis yang digunakan adalah analisis kualitatif. ${ }^{11}$ Berhubung penelitian ini merupakan penelitian hukum normatif, maka analisis data yang digunakan adalah analisis kualitatif atau lebih tepatnya disebut analisis yuridis kualitatif, karena yang dianalisis adalah informasi yang didapat dari peraturan perundangundang dan karya ilmiah dalam bidang hukum.

\section{Hasil Penelitian dan Analisis}

\section{Konsep teoritis tentang kepastian hukum}

Secara umum konsep negara hukum pada prinsipnya mencakup empat tuntutan dasar, yakni: (a) kepastian hukum; (b) hukum berlaku sama bagi seluruh penduduk; (c) adanya legitimasi demokratis dalam pembuatan hukum; serta (d) menjunjung tinggi martabat manusia. ${ }^{12}$ Hans Kelsen dalam pandangannya mengatakan bahwa konsep rule of law (negara hukum) yang berarti penegakan hukum, maka: (a) hukum ditegakkan demi kepastian hukum; (b) hukum itu dijadikan sumber utama bagi hakim dalam memutuskan perkara; (c) hukum tidak didasarkan pada kebijaksanaan dalam pelaksanaannya; dan (e) hukum itu harus bersifat dogmatik. ${ }^{13}$

Terhadap istilah kepastian hukum, ada beberapa pengertian yang dapat dikemukakan. Menurut Sudikno Mertokusumo, ${ }^{14}$ kepastian hukum merupakan perlindungan yustisiabel terhadap tindakan sewenang-wenang yang berarti bahwa seseorang akan dapat memperoleh sesuatu yang diharapkan dalam keadaan tertentu. Berdasarkan terjemahan resmi dari Badan Pembinaan Hukum Nasional $(\mathrm{BPHN}),{ }^{15}$ disebutkan bahwa kepastian hukum (rechtszekerheid) merupakan jaminan bagi anggota masyarakat bahwa hukum akan diterapkan secara benar dan

\footnotetext{
${ }^{11}$ Salim HS dan Erlies Septiana Nurbaini. 2013. Penerapan Teori Hukum pada Penelitian Tesis dan Disertasi. Jakarta: RajaGrafindo Persada. Hlm. 18.

${ }^{12}$ Arif Hidayat. "Kepastian Hukum Harus Sejalan dengan Rasa Keadilan" dalam Antara News, http://www.antaranews.com. Diakses tanggal 12 Maret 2017.

${ }^{13}$ Astim Riyanto. 2002. Filsafat Hukum. Bandung: Yapemdo. Hlm. 377.

14 Sudikno Mertokusumo. 1993. Bab-bab tentang Penemuan Hukum. Bandung: Citra Aditya Bakti. Hlm. 1-2.

15 BPHN. 1997/1998. Penyusunan Kamus Hukum Umum Bahasa Belanda-Bahasa Indonesia. Jakarta: BPHN-Departemen Kehakiman dan HAM RI. Hlm. 122.
} 
adil, sedangkan dalam Kamus Besar Bahasa Indonesia, ${ }^{16}$ disebutkan bahwa kepastian hukum adalah perangkat hukum suatu negara yang mampu menjamin hak dan kewajiban setiap warga negara.

Menurut Jimly Ashiddiqie bahwa dalam hukum harus ada keadilan dan kepastian hukum dan kepastian hukum itu penting agar orang tidak bingung, tetapi keadilan dan kepastian hukum itu sendiri merupakan dua sisi dari satu mata uang. Antara keadilan dan kepastian hukum tak perlu dipertentangkan. Kalimatnya tidak boleh dipotong, berarti keadilan pasti identik dengan kepastian yang adil. Kalau ketidakpastian itu terjadi, berarti terjadi ketidakadilan bagi banyak orang. Jangan karena ingin mewujudkan keadilan bagi satu orang, tapi justru menciptakan ketidakadilan bagi banyak orang. Selain harus ada kepastian hukum, tujuan hukum adalah untuk mewujudkan keadilan dan keteraturan. Keadilan, kepastian hukum, dan keteraturan itu harus diwujudkan secara simultan agar tercipta kedamaian hidup bersama. ${ }^{17}$

Kepastian hukum mempunyai dua segi, yaitu: (a) soal dapat ditentukannya (bepaalbaarheid) hukum dalam hal-hal yang kongkrit, artinya pihak yang mencari keadilan ingin mengetahui yang menjadi hukumnya dalam hal yang khusus, sebelum memulai perkara, dan (b) kepastian hukum berarti keamanan hukum, artinya perlindungan bagi para pihak terhadap kesewenangan hakim. ${ }^{18}$ Reinhold Zippelius juga membedakan kepastian hukum dalam dua pengertian, yaitu: ${ }^{19}$

a. Kepastian dalam pelaksanaannya, maksudnya bahwa hukum yang resmi diundangkan dilaksanakan dengan pasti oleh negara. Setiap orang dapat menuntut agar hukum dilaksanakan dan tuntutan itu pasti dipenuhi dan setiap pelanggaran hukum akan ditindak dan dikenakan sanksi menurut hukum juga.

\footnotetext{
${ }^{16}$ Pusat Bahasa Departemen Pendidikan Nasional. 2002. Kamus Besar Bahasa Indonesia. Jakarta: Balai Pustaka. Hlm. 835.

17 Jimly Ashiddiqie. "Keadilan, Kepastian Hukum dan Keteraturan," http://www. suarakarya-online.com. Diakses tanggal 12 Maret 2017.

${ }^{18}$ L.J. Van Apeldoorn dalam Darji Darmodiharjo dan Shidarta. 1996. Penjabaran Nilainilai Pancasila dalam Sistem Hukum Indonesia. Jakarta: Rajawali Pers. Hlm. 44.

${ }^{19}$ Franz Magnis Suseno. 2001. Etika Politik. Jakarta: Gramedia Pustaka Utama. Hlm. 7980. Bandingkan juga dengan Budiono Kusumohamidjojo, yang membedakan antara: (1) kepastian dalam orientasi bagi masyarakat (orientierungssicherbeit/certitudo); dan (2) kepastian dalam penetapan hukum oleh penegak hukum (realisierungssicherbeir/securitas). Lihat dalam Budiono Kusumohamidjojo. 1999. Ketertiban yang Adil (Problematik Fisafat Hukum). Jakarta: Grasindo. Hlm. 153-154.
} 
b. Kepastian orientasi, maksudnya bahwa hukum itu harus jelas, sehingga masyarakat dan hakim dapat berpedoman padanya. Hal ini berarti bahwa setiap istilah dalam hukum harus dirumuskan dengan terang dan tegas sehingga tak ada keragu-raguan tentang tindakan apa yang dimaksud. Begitu pula aturan-aturan hukum harus dirumuskan dengan ketat dan sempit agar keputusan dalam perkara pengadilan tidak dapat menurut tafsiran subyektif dan selera pribadi hakim. Kepastian orientasi menuntut agar ada prosedur pembuatan dan peresmian hukum yang jelas dan dapat diketahui umum. Kepastian orientasi ini juga menuntut agar hukum dikembangkan secara kontinu dan taat asas. Undang-undang harus saling kait mengkait, harus menunjuk ke satu arah agar masyarakat dapat membuat rencana ke masa depan, begitu pula jangan dibuat undang-undang yang saling bertentangan.

Mochtar Kusumaatmadja mengatakan bahwa selain ketertiban, tujuan lain dari hukum adalah tercapainya keadilan yang berbeda-beda isi dan ukurannya menurut masyarakat dan zamannya. Untuk mencapai ketertiban masyarakat ini, diperlukan kepastian hukum pergaulan antarmanusia dalam di masyarakat. ${ }^{20}$ Negara hukum bertujuan untuk menjamin bahwa kepastian hukum dapat terwujud dalam masyarakat. Hukum bertujuan untuk mewujudkan kepastian dalam hubungan antar manusia, yaitu menjamin prediktabilitas, dan juga bertujuan untuk mencegah bahwa hak yang terkuat yang berlaku, beberapa asas yang terkandung dalam asas kepastian hukum adalah: ${ }^{21}$

a. asas legalitas, konstitusionalitas dan supremasi hukum;

b. asas undang-undang menetapkan berbagai perangkat aturan tentang cara pemerintah dan pejabatnya melakukan tindakan pemerintahan;

c. asas non retroaktif perundang-undangan: sebelum mengikat, undang-undang harus diumumkan secara layak;

d. asas non liquet: hakim tidak boleh menolak perkara yang dihadapkan kepadanya dengan alasan undang-undang tidak jelas atau tidak ada;

e. asas peradilan bebas: objektif imparsial dan adil manusiawi; dan

f. hak asasi manusia harus dirumuskan dan dijamin perlindungannya dalam Undang Undang Dasar.

\footnotetext{
${ }^{20}$ Mochtar Kusumaatmadja (Editor: R. Otje Salman S. dan Edi Damian). 2006. Konsepkonsep Hukum dalam Pembangunan (Kumpulan Karya Tulis). Cetakan Kedua. Bandung: Alumni. Hlm. 3-4.

${ }^{21}$ Malik Ibrahim. Asas Kepastian Hukum (Rule of Law Principle). http://alikibe.blogspot. com. Diakses tanggal 12 Maret 2017.
} 
Secara normatif kepastian hukum dapat terwujud jika peraturan dibuat dan diundangkan secara pasti karena mengatur secara jelas dan logis. Jelas dalam pengertian tidak menimbulkan keragu-raguan (multitafsir) dan logis dalam pengertian menjadi suatu sistem norma dengan norma lain sehingga tidak berbenturan atau menimbulkan konflik norma. Konflik norma yang ditimbulkan dari ketidakpastian aturan dapat berbentuk kontestasi norma, reduksi norma atau distorsi norma. ${ }^{22}$

Menurut Achmad Ali bahwa ada empat hal yang berhubungan dengan makna kepastian hukum, yaitu: ${ }^{23}$

a. hukum itu positif, artinya bahwa ia adalah perundang-undangan;

b. hukum itu didasarkan pada fakta, bukan suatu rumusan tentang penilaian yang nanti akan dilakukan oleh hakim;

c. fakta itu itu harus dirumuskan dengan cara yang jelas, sehingga menghindari kekeliruan dalam pemaknaan, selain juga mudah dilaksanakan; dan d. hukum positif itu tidak boleh sering diubah-ubah.

Kepastian hukum dalam hubungannya dengan masyarakat terlihat jelas ketika umumnya masyarakat mematuhi atau melaksanakan aturan hukum, sebaliknya apabila hukum tidak dipatuhi berarti dapat dikatakan bahwa hukum belum lagi menjamin terciptanya kepastian hukum. Ada banyak faktor yang menyebabkan masyarakat tidak atau kurang mematuhi hukum (dalam pengertian undang-undang) dan faktor utamanya karena hukum dirasakan bertentangan dengan jalinan nilai-nilai dan kesadaran hukum yang tumbuh dan berkembang dalam kehidupan masyarakat. Oleh sebab itu, demi terciptanya kepastian hukum, maka suatu produk hukum hendaknya dapat diselaraskan dengan nilai-nilai dan cita-cita hukum masyarakat itu sendiri, yang di Indonesia adalah Pancasila sebagai landasan filosofis dan UUD 1945 sebagai landasan konstitusional.

22 Yance Arizona. “Apa Itu Kepastian Hukum”. http://yancearizona.wordpress.com. Diakses tanggal 12 Maret 2017.

23 Achmad Ali. 2009. Menguak Teori Hukum (Legal Theory) dan Teori Peradilan (Judicial Prudence) Termasuk Interpretasi Undang-undang (Legisprudence). Edisi Pertama. Cetakan Kedua. Jakarta: Kencana. Hlm. 293. 


\section{Hak menguasai negara dalam perspektif negara hukum berdasarkan Pancasila}

Pancasila merupakan sumber dari segala sumber hukum dan hal ini yang membedakan konsep negara hukum Indonesia dengan konsep negara hukum yang dianut atau berkembang di negara lain, walaupun sebenarnya pemikiran tentang negara hukum telah mengalami perkembangan dalam berbagai situasi sejarah peradaban manusia. Konsep negara hukum memang dianggap sebagai konsep universal yang diakui bangsa-bangsa beradab, tetapi pada tataran implementasinya memiliki ciri-ciri dan karakter beragam. Hal ini terjadi karena pengaruh situasi kesejarahan dan falsafah bangsa, faham filsafat dan ideologi politik suatu negara. $^{24}$

Hakikat negara hukum didasarkan pada konsep teori Kedaulatan Negara (Soeverignty) yang pada prinsipnya menyatakan kekuasaan tertinggi di dalam suatu negara adalah hukum. Seluruh alat perlengkapan negara apa pun namanya, termasuk warga negara harus tunduk dan patuh serta menjunjung tinggi hukum tanpa kecuali. ${ }^{25}$ Konsep pemikiran negara hukum seperti ini sebenarnya dapat dilihat dari awal munculnya teori Negara Hukum yang dimulai sejak abad XIX hingga abad $\mathrm{XX} .^{26}$

Istilah negara hukum di Indonesia sering disebut rechtstaats atau the rule of law. Paham rechtstaats pada dasarnya bertumpu pada sistem hukum Eropa Kontinental dan walaupun dalam UUD 1945 istilah negara hukum disebut rechtstaats, tetapi secara normatif harus dibedakan dengan paham negara hukum dalam sistem hukum Eropa Kontinental ataupun konsep the rule of law dalam sistem hukum Anglo Saxon. Konsep negara hukum (rechtstaats) di Indonesia harus sesuai dengan nilai-nilai yang tercermin dalam Pancasila. Pemahaman utuh

${ }^{24}$ Tengku Erwinsyahbana. 2012. "Kajian atas Kepastian Hukum Perkawinan Antar Agama Dikaitkan dengan Sistem Hukum Perkawinan Indonesia dalam Perspektif Pembangunan Hukum Keluarga Nasional". Disertasi. Bandung: Fakultas Hukum Program Doktor Ilmu Hukum Pascasarjana Universitas Padjadjaran. HIm. 22.

${ }^{25}$ B. Hestu Cipto Handoyo. 2003. Hukum Tata Negara, Kewarganegaraan \& Hak Asasi Manusia, Memahami Proses Konsolidasi Sistem Demokrasi di Indonesia. Cetakan Pertama. Yogyakarta: Universitas Atma Jaya. Hlm. 12.

${ }^{26}$ Krisna Harahap. 2003. HAM dan Upaya Penegakannya di Indonesia. Bandung: Grafitri Budi Utami. Hlm. 22. 
terhadap konsep Negara Hukum yang berdasarkan Pancasila dapat dilihat dari proses dan latar belakang lahirnya rumusan Pembukaan UUD 1945 yang merupakan pernyataan kehendak lahirnya negara Indonesia, serta sebagai dasar filosofis dan tujuan negara. Dari kajian dan pemahaman demikian, akan sampai pada suatu kesimpulan bahwa dalam konsep Negara Hukum yang berdasarkan Pancasila selain memiliki kesamaan, tetapi juga memiliki perbedaan dengan konsep negara hukum yang dikembangkan di negara lain. ${ }^{27}$

Unsur-unsur negara hukum Indonesia merupakan nilai yang dipetik dari seluruh proses lahirnya negara Indonesia, dasar falsafah serta cita hukum negara Indonesia. Oleh sebab itu, kedudukan Pembukaan UUD 1945 yang juga memuat rumusan Pancasila, menjadi sumber hukum tertinggi bagi negara hukum Indonesia. Pembukaan UUD 1945 merupakan nilai abstraksi tertinggi dan nilai yang terkandung dalam pembukaan merupakan kaedah penuntun penyusunan pasal-pasal dalam UUD 1945 agar tidak menyimpang dari nilai-nilai yang menjadi dasar falsafah dan cita negara. ${ }^{28}$

Kedudukan Pancasila dalam sistem ketatanegaraan Indonesia adalah sebagai staatsfundamentalnorm. Jimly Asshiddiqie dan M. Ali Safa'at dikatakan bahwa penempatan Pancasila sebagai staatsfundamentalnorm pertama kali disampaikan Notonagoro. ${ }^{29}$ Pancasila dilihat sebagai cita hukum (rechtsidee) merupakan bintang pemandu. Posisi ini mengharuskan pembentukan hukum positif adalah untuk mencapai ide-ide dalam Pancasila, serta dapat digunakan untuk menguji hukum positif. Dengan ditetapkannya Pancasila sebagai staats-

\footnotetext{
${ }^{27}$ Negara hukum dalam perspektif Pancasila, selain memiliki elemen-elemen yang sama dengan elemen negara hukum dalam rechtstaat maupun rule of law, juga memiliki elemen-elemen yang spesifik yang menjadikan Negara Hukum Indonesia berbeda dengan konsep negara hukum yang dikenal secara umum. Perbedaan itu terletak pada nilai-nilai yang terkandung dalam Pembukaan UUD 1945 yang di dalamnya mengandung Pancasila dengan prinsip-prinsip Ketuhanan Yang Maha Esa, serta tidak adanya pemisahan antara negara dan agama, prinsip musyawarah dalam pelaksanaan kekuasaan pemerintahan negara, prinsip keadilan sosial, kekeluargaan dan gotong royong serta hukum yang mengabdi pada keutuhan negara kesatuan Indonesia. Lihat dalam Tengku Erwinsyahbana. Op. Cit. Hlm. 26

${ }^{28}$ Ibid. Hlm. 27.

${ }^{29}$ Notonagoro. t.t. "Pembukaan Undang-Undang Dasar 1945 (Pokok Kaidah Fundamentil Negara Indonesia" dalam Pancasila Dasar Falsafah Negara. Cetakan Keempat. Jakarta: Pantjuran Tudjuh. Lihat juga dalam Jimly Asshiddiqie dan M. Ali Safa'at. 2006. Teori Hans Kelsen tentang Hukum. Cetakan Pertama. Jakarta: Sekretariat Jenderal \& Kepaniteraan Mahkamah Konstitusi RI. Hlm. 171.
} 
fundamentalnorm maka pembentukan hukum, penerapan dan pelaksanaannya tidak dapat dilepaskan dari nilai-nilai Pancasila. ${ }^{30}$

Mengingat bahwa Pembukaan UUD 1945 yang merupakan pernyataan kehendak lahirnya negara Indonesia, serta sebagai dasar filosofis dan tujuan Negara, dan sekaligus sebagai kaedah penuntun penyusunan pasal-pasal dalam Batang Tubuh UUD 1945, maka salah satu tujuan Negara Republik Indonesia, yaitu untuk memajukan kesejahteraan umum, dimuat dalam Pasal 33 yang mengamanatkan bahwa: (a) cabang-cabang produksi yang penting bagi negara dan yang menguasai hidup orang banyak, dikuasai oleh negara; dan (b) bumi, air, serta kekayaan alam yang terkandung di dalamnya dikuasai oleh negara dan dipergunakan untuk sebesar-besarnya kemakmuran rakyat.

Maksud istilah "dikuasai negara" sempat menjadi bahan perdebatan, seperti misalnya Mohammad Hatta dan Muhammad Yamin. Menurut Mohammad Hatta dikatakan bahwa: pengertian dikuasai oleh negara adalah dikuasai oleh negara tidak berarti negara sendiri jadi pengusaha, usahawan atau ordernemer, dan lebih tepat dikatakan bahwa kekuasaan negara terdapat pada membuat peraturan guna kelancaran jalan ekonomi, peraturan yang melarang pula penghisapan orang yang lemah oleh orang yang bermodal, ${ }^{31}$ sedangkan Muhammad Yamin, mengatakan bahwa: pengertian dikuasai oleh negara termasuk mengatur dan/atau menyelenggarakan terutama untuk memperbaiki dan mempertinggi produksi dengan mengutamakan koperasi. ${ }^{32}$

Panitia Keuangan dan Perekonomian bentukan Badan Penyelidik Usahausaha Persiapan Kemerdekaan Indonesia (BPUPKI), yang diketuai Mohammad Hatta, merumuskan pengertian dikuasai oleh negara sebagai berikut: ${ }^{33}$

30 A. Hamid S. Attamimi, "Peranan Keputusan Presiden Republik Indonesia dalam Penyelenggaraan Pemerintahan Negara: Suatu Studi Analisis Mengenai Keputusan Presiden yang Berfungsi Pengaturan dalam Kurun Waktu Pelita I-Pelita IV”, Disertasi, Jakarta: Fakultas Pascasarjana Universitas Indonesia, 1990, hlm. 309.

${ }^{31}$ Mohammad Hatta. 1977. Penjabaran Pasal 33 Undang-Undang Dasar 1945. Jakarta: Mutiara. Hlm. 28.

${ }^{32}$ Muhammad Yamin. 1954. Proklamasi dan Konstitusi. Jakarta: Djembatan. Hlm. 42.

33 Pan Mohamad Faiz. "Penafsiran Konsep Penguasaan Negara Berdasarkan Pasal 33 UUD 1945 dan Putusan Mahkamah Konstitusi”. http://dosen.narotama.ac.id. Diakses tanggal 12 Maret 2017. 
a. pemerintah harus menjadi pengawas dan pengatur dengan berpedoman keselamatan rakyat;

b. semakin besarnya perusahaan dan semakin banyaknya jumlah orang yang menggantungkan dasar hidupnya karena semakin besar mestinya persertaan pemerintah;

c. tanah haruslah di bawah kekuasaan negara; dan

d. perusahaan tambang yang besar dijalankan sebagai usaha negara.

Dalam pandangan lain yang dikemukakan oleh Bagir Manan, dirumuskan cakupan pengertian dikuasai oleh negara atau hak penguasaan negara dalam 3 (tiga) bentuk, yaitu: (a) penguasaan semacam pemilikan oleh negara, artinya negara melalui pemerintah adalah satu-satunya pemegang wewenang untuk menentukan hak wewenang atasnya, termasuk di sini bumi, air, dan kekayaan yang terkandung di dalamnya, (b) mengatur dan mengawasi penggunaan dan pemanfaatan, serta (c) penyertaan modal dan dalam bentuk perusahaan negara untuk usaha-usaha tertentu. ${ }^{34}$

Pasal 33 UUD 1945 merupakan landasan konstitusional untuk melaksanakan pembangunan perekonomian negara, dan berdasarkan ketentuan dasar ini dapat diketahui bahwa kemakmuran rakyat merupakan tujuan utama dalam pemanfaatan fungsi bumi, air dan ruang angkasa, serta kekayaan alam yang terkandung di dalamnya. Sebagai wujud nyata penerapan Pasal 33 UUD 1945 dalam peraturan perundang-undangan di Indonesia, pertama kali dituangkan dalam Undang-undang Nomor 5 Tahun 1960 tentang Peraturan Dasar Pokokpokok Agraria (UUPA), yang pada Pasal 2 ayat (1), ditegaskan bahwa bumi, air dan ruang angkasa termasuk kekayaan alam di dalamnya pada tingkat yang tertinggi dikuasai oleh negara sebagai organisasi kekuasaan seluruh rakyat.

Ketentuan yang terdapat dalam 33 ayat 3 UUD 1945 dan Pasal 2 ayat (1) UUPA, memberikan kewenangan kepada negara untuk mengatur pengelolaan aspek-aspek dalam bidang agraria, yang lazim dikenal dengan istilah asas hak mengusai negara, dan melalui hak menguasai negara, maka negara selaku badan

34 Bagir Manan. 1995. Pertumbuhan dan Perkembangan Konstitusi Suatu Negara. Bandung: Mandar Maju. Hlm. 12. 
penguasa harus senantiasa mengendalikan atau mengarahkan pengelolaan fungsi bumi, air dan ruang angkasa, serta kekayaan alam yang terkandung di dalamnya sesuai dengan peraturan dan kebijakan yang ada, yaitu dalam lingkup penguasaan secara yuridis yang beraspek publik. ${ }^{35}$

Sejak berlakunya UUPA, maka makna hak menguasi negara ini dijabarkan dalam Pasal 2 ayat (2) UUPA, yang menentukan bahwa: (a) negara diberi wewenang untuk mengatur, menyelenggarakan peruntukan dan penggunaan bumi, air dan ruang angkasa; (b) menentukan dan mengatur hubungan-hubungan hukum antara orang-orang dengan bumi, air dan ruang angkasa; serta (c) menentukan dan mengatur hubungan-hubungan hukum antara orang-orang dan perbuatanperbuatan hukum yang mengenai bumi, air dan ruang angkasa. Berpedoman pada kewewenangan negara ini, maka negara dapat memberikan tanah pada seseorang dan badan hukum dengan sesuatu hak menurut peruntukkan dan keperluannya, tetapi kekuasaan negara untuk memberikan hak dimaksud juga dibarengi oleh kekuasaan negara untuk mencabut hak-hak yang diberikan. ${ }^{36}$

Istilah hak menguasai negara atas tanah yang semula berasal dari Pasal 33 UUD Dasar 1945, yang kemudian dijabarkan dalam Pasal 2 ayat (2) UUPA tidak menunjukan arti bahwa negara bertindak sebagai pemilik tanah. Hak menguasai negara atas tanah bersumber dari hak bangsa Indonesia, pada hakikatnya merupakan penugasan pelaksanaan kewenangan bangsa yang mengandung unsur hukum publik. Tugas mengelola seluruh tanah tidak mungkin dilakukan secara bersama oleh bangsa Indonesia, maka dalam penyelenggaraannya, bangsa Indonesia sebagai pemegang hak dan pengemban amanat tersebut menguasakan kepada negara sebagai organisasi kekuasaan seluruh rakyat. ${ }^{37}$

Pengertian dikuasai negara ini juga dijabarkan lebih lanjut dalam Putusan Mahkamah Konstitusi Nomor 001-021-022/PUU-I/2003, tentang Pengujian Undang-undang Nomor 20 Tahun 2002 tentang Ketenagalistrikan terhadap

${ }^{35}$ Muhammad Bakri. 2007. Hak Menguasai Tanah oleh Negara (Paradigma Baru untuk Reformasi Agraria). Yogyakarta: Citra Media. Hlm. 5.

${ }^{36}$ Asdar Kadir, "Hak Menguasai Negara Atas Tanah Sebagai Dasar Perampasan Hak Perseorangan Atas Tanah (Tinjauan terhadap Pengadaan Hak Atas Tanah Demi Kepentingan Umum)”, http://asdarkadir.blogspot.com. Diakses tanggal 12 Maret 2014.

${ }^{37}$ Ibid. 
Undang Undang Dasar Negara Republik Indonesia Tahun 1945, yang dimuat dalam Berita Negara Republik Indonesia Nomor 102 Tahun 2004, tanggal 21 Desember 2004, sebagai berikut:

Perkataan "dikuasai oleh negara" haruslah diartikan mencakup makna penguasaan oleh negara dalam arti luas yang bersumber dan berasal dari konsepsi kedaulatan rakyat Indonesia atas segala sumber kekayaan "bumi dan air dan kekayaan alam yang terkandung di dalamnya", termasuk pula di dalamnya pengertian kepemilikan publik oleh kolektivitas rakyat atas sumber-sumber kekayaan dimaksud. Rakyat secara kolektif itu dikonstruksikan oleh UUD 1945 memberikan mandat kepada negara untuk mengadakan kebijakan (beleid) dan tindakan pengurusan (bestuursdaad), pengaturan (regelendaad), pengelolaan (beheersdaad) dan pengawasan (toezichthoudensdaad) untuk tujuan sebesar-besarnya kemakmuran rakyat. Fungsi pengurusan (bestuursdaad) oleh negara dilakukan oleh pemerintah dengan kewenangannya untuk mengeluarkan dan mencabut fasilitas perizinan (vergunning), lisensi (licentie), dan konsesi (concessie). Fungsi pengaturan oleh negara (regelendaad) dilakukan melalui kewenangan legislasi oleh DPR bersama dengan Pemerintah, dan regulasi oleh Pemerintah (eksekutif). Fungsi pengelolaan (beheersdaad) dilakukan melalui mekanisme pemilikan saham (share-holding) dan/atau melalui keterlibatan langsung dalam manajemen Badan Usaha Milik Negara atau Badan Hukum Milik Negara sebagai instrumen kelembagaan melalui mana negara c.q. Pemerintah mendayagunakan penguasaannya atas sumber-sumber kekayaan itu untuk digunakan bagi sebesar-besarnya kemakmuran rakyat. Demikian pula fungsi pengawasan oleh negara (toezichthoudensdaad) dilakukan oleh negara c.q. Pemerintah dalam rangka mengawasi dan mengendalikan agar pelaksanaan penguasaan oleh negara atas cabang produksi yang penting dan/atau yang menguasai hajat hidup orang banyak dimaksud benar-benar dilakukan untuk sebesarbesarnya kemakmuran seluruh rakyat.

Melihat putusan ini, ternyata Mahkamah Konstitusi dalam pertimbangan hukumnya memaknai istilah (konsep) "hak menguasai negara”, menjadi 5 (lima), yaitu:

a. negara merumuskan kebijakan (beleid);

b. negara melakukan pengaturan (regelendaad);

c. negara melakukan pengurusan (bestuursdaad);

d. negara melakukan pengelolaan (beheersdaad); dan

e. negara melakukan pengawasan (toezichthoundendaad).

Berdasarkan penjelasan di atas, maka dapat diasumsikan bahwa konsepsi kewenangan negara yang terkandung dalam makna hak menguasai negara harus 
dipahami dalam kerangka hubungan antara negara dengan bumi, air dan kekayaan alam yang terkandung di dalamnya sebagai hubungan penguasaan, bukan hubungan kepemilikan. Negara merupakan badan penguasa yang pada tingkatan tertinggi berwenang mengatur pemanfaatan dan pengelolaan sumber daya alam, serta untuk menentukan dan mengatur hubungan hukum dan perbuatan hukum yang berkenaan dengan pemanfaatan dan pengelolaan sumber daya alam, dan salah satu perwujudan hak menguasai negara yang perlu mendapat perhatian serius adalah kegiatan pengelolaan pertambangan.

Negara harus mengatur kegiatan pengelolaan pertambangan di Indonesia secara hati-hati, karena pada satu sisi pengelolaan sumber daya pertambangan mutlak diperlukan dalam rangka pelaksanaan pembangunan untuk menuju masyarakat Indonesia yang sejahtera, tetapi pada sisi lain, jika pengelolaannya dilakukan tidak secara optimal tanpa memperhatikan cadangan masa depan dan kelestarian fungsi lingkungan hidup, dapat dipastikan bahwa dalam beberapa dasawarsa ke depan, Indonesia tidak lagi mempunyai cadangan sumber daya alam yang dapat dijadikan modal dasar bagi upaya pembangunan perekonomian masyarakat dan negara

Mengingat konsepsi hak menguasai negara sebagaimana dikemukakan di atas, maka negara harus dapat menjalankan peran dan fungsinya untuk merumuskan peraturan perundang-undangan dan kebijakan, serta melakukan pengurusan dan pengawasan terhadap semua kegiatan terkait dengan masalah pengelolaan sumber daya pertambangan, salah satunya adalah menyangkut dengan penerbitan izin usaha bidang pertambangan. Tindakan ini mutlak dilakukan, karena akan bersentuhan langsung dengan berbagai aspek lainnya, seperti: kepastian hukum dalam berusaha, kepastian hukum terhadap hak-hak ekonomi dan sosial masyarakat di wilayah pertambangan, kepastian hukum terhadap hak-hak atas tanah, perlindungan terhadap fungsi kelestarian lingkungan hidup dan berbagai aspek lainnya. ${ }^{38}$

\footnotetext{
${ }^{38}$ M. Said Saile, Zulkarnaen Koto, Tengku Erwinsyahbana. 2012. "'Sinkronisasi Peraturan Perundang-undangan Guna Efektivitas Penerbitan Izin Usaha Bidang Pertambangan Dalam Rangka Ketahanan Nasional". Jakarta: Lembaga Ketahanan Nasional Republik Indonesia. Hlm. 2. Dari https://erwin6768.blogspot.co.id. Diakses tanggal 20 Maret 2017.
} 


\section{Kontrak karya dalam perspektif asas hak menguasai negara}

Pertambangan Gesberg dan Esberg yang dilaksanakan Freeport, merupakan pertambangan mineral pertama di Indonesia, yaitu pengusahaan terhadap mineral berupa logam mulia yang meliputi tembaga, emas, perak, platina dan palladium. Pertambangan ini dilakukan melalui kerja sama antara Pemerintah Indonesia dengan P.T. Freeport Indonesia, yang dituangkan dalam suatu kontrak karya pada tahun 1967. Kontrak karya ini dibuat atas dasar UU No. 11 Tahun 1967 dan UU No. 1 Tahun 1967, dan diketahui bahwa perundingan yang terjadi antara Pemerintah dengan P.T. Freeport berlangsung dengan tidak adil, karena pihak Pemerintah Indonesia saat itu hanya diwakili oleh seorang pengacara dari PT. Freeport Indonesia. Hal ini terjadi karena pengetahuan dari pihak Pemerintah sangat minim terkait penanaman modal asing dan pertambangan. ${ }^{39}$

Terkait dengan kontrak karya tersebut, dapat diperhatikan asas dalam hukum perjanjian, yang dikenal dengan "asas pacta sunt servanda", yang berarti bahwa setiap perjanjian menjadi hukum yang mengikat bagi para pihak yang melakukan perjanjian. Asas ini juga dianut dalam hukum perdata yang berlaku di Indonesia, sebagaimana yang tertuang dalam Pasal 1338 Kitab Undang-undang Hukum Perdata (KUH Perdata) yang menentukan bahwa semua persetujuan yang dibuat secara sah sesuai dengan undang-undang berlaku sebagai undang-undang bagi mereka yang membuatnya.

Kalimat "yang dibuat secara sah sesuai dengan undang-undang", mengandung arti bahwa walaupun para pihak bebas mengadakan dan menentukan isi perjanjian, tetapi perjanjian tersebut tidak boleh bertentangan dengan undangundang. Hal ini juga dituangkan dalam Pasal 1320 KUH Perdata, yang menentukan bahwa salah satu syarat sahnya perjanjian adalah terpenuhi suatu sebab yang halal, dan apabila syarat ini tidak terpenuhi, maka perjanjian demikian adalah batal demi hukum. Pasal 1337 KUH Perdata menentukan bahwa suatu sebab adalah terlarang, apabila dilarang oleh undang-undang, atau apabila berlawanan

39 Agustin Tri Setiyani, Ery Agus Priyono, Agung Basuki. 2013. "Tinjauan Yuridis Penerapan Asas Proporsionalitas Renegosiasi Kontrak Karya antara Pemerintah Indonesia dengan P.T. Freeport Indonesia”. Diponegoro Law Review. Volume 1. Nomor 2. Dari http://ejournals1.undip.ac.id. Diakses tanggal 19 Maret 2017. 
dengan kesusilaan baik atau ketertiban umum, dan oleh sebab itu suatu perjanjian dikatakan telah memenuhi suatu sebab yang halal, apabila:

a. tidak bertentangan dengan undang-undang; dan/atau

b. tidak bertentangan dengan kesusilaan; dan/atau

c. tidak bertentangan dengan ketertiban umum.

Mengingat posisi Pemerintah Indonesia sebagai salah satu pihak dalam kontrak karya tersebut, maka hal yang perlu dipertanyakan adalah terkait dengan posisinya sebagai badan hukum, dan apabila mengacu pada Pasal 1653 dan Pasal 1654 KUH Perdata, maka peran Pemerintah Indonesia sebagai badan hukum publik dapat pula melakukan perbuatan-perbuatan hukum dalam lapangan hukum privat. ${ }^{40}$ Memperhatikan isi Pasal 1653 dan Pasal 1654 KUH Perdata, maka ada 6 (enam) aspek hukum yang perlu diperhatikan, yaitu:

a. badan hukum itu diadakan oleh kekuasaan umum;

b. badan hukum itu diakui oleh kekuasaan umum;

c. badan hukum itu diterima dan diperkenankan atau didirikan untuk suatu tujuan tertentu;

d. Tujuan badan hukum itu tidak bertentangan dengan undang-undang atau kesusilaan;

e. Badan hukum itu berkuasa (berwenang) melakukan perbuatan-perbuatan perdata; dan

f. Kewenangan badan hukum tidak boleh mengurangi (bertentangan dengan) peraturan perundang-undangan.

Berdasarkan ketentuan di atas, terlihat bahwa Pemerintah Indonesia pada satu sisi dapat saja melaksanakan perbuatan perdata, yaitu berupa kontrak karya dengan pihak P.T. Freeport Indonesia, tetapi jika memperhatikan konsep yuridis asas hak menguasai negara, maka peran Pemerintah Indonesia sebagai organ

40 Pasal 1653 KUH Perdata menentukan bahwa selain perseroan perdata sejati, perhimpunan orang-orang sebagai badan hukum juga diakui undang-undang, entah badan hukum itu diadakan oleh kekuasaan umum atau diakuinya sebagai demikian, entah pula badan hukum itu diterima sebagai yang diperkenankan atau telah didirikan untuk suatu maksud tertentu yang tidak bertentangan dengan undang-undang atau kesusilaan, sedangkan Pasal 1653 KUH Perdata menentukan bahwa semua badan hukum yang berdiri dengan sah, begitu pula orang-orang swasta, berkuasa untuk melakukan perbuatan-perbuatan perdata, tanpa mengurangi perundang-undangan yang mengubah kekuasaan itu, membatasinya atau menundukkannya kepada tata cara tertentu. 
negara seharusnya tidak menjadi salah satu pihak dengan kontrak karya dalam eksploitasi dan eksplorasi kekayaan alam di Indonesia, melainkan harus berperan sebagai pengelolanya. Alasannya, karena dikuasai oleh negara tidak berarti negara sendiri menjadi pengusaha, usahawan atau ordernemer, dan pengertian dikuasai termasuk untuk mengatur dan/atau menyelenggarakan, bahkan rumusan yang diberikan Panitia Keuangan dan Perekonomian bentukan Badan Penyelidik Usaha-usaha Persiapan Kemerdekaan Indonesia (BPUPKI), pengertian dikuasai oleh negara antara lain: perusahaan tambang yang besar dijalankan sebagai usaha negara.

Fakta yang terjadi dalam kontrak karya pertambangan di Kabupaten Mimika (Papua), dilakukan oleh pihak asing, walaupun pengelolaannya dilakukan oleh perusahaan yang berstatus badan hukum Indonesia (P.T. Freeport Indonesia), pada sisi lain negara tidak berperan dalam pengelolaan pertambangan tersebut, melainkan hanya pihak yang menerima pendapatan dari pajak pertambangan. Hal ini tentunya telah bertentangan dengan asas hak menguasai negara sebagaimana tertuang dalam Pasal 33 UUD 1945, oleh sebab itu syarat sah perjanjian sebagai tertuang dalam Pasal 1320 KUH Perdata (suatu sebab yang halal) tidak terpenuhi, demikian juga jika berpedoman pada isi Pasal 1653 dan Pasal 1654 KUH Perdata. Atas dasar ini dapat dikatakan bahwa kontrak karya pertambangan antara Pemerintah Indonesia dengan P.T. Freeport Indonesia harus dianggap tidak mempunyai kekuatan mengikat.

Adanya kontrak karya pertambangan tersebut yang dilihat dari orientasinya telah menimbulkan ketidakpastian hukum, karena kepastian orientasi ini menuntut agar hukum dikembangkan secara kontinu dan taat asas. Selain itu undang-undang harus saling kait mengkait, harus menunjuk ke satu arah agar masyarakat dapat membuat rencana ke masa depan, begitu pula jangan dibuat undang-undang yang saling bertentangan, dan oleh sebab itu, demi terciptanya kepastian hukum, kontrak karya pertambangan tersebut hendaknya dapat diselaraskan dengan nilai-nilai dan cita-cita hukum masyarakat itu sendiri, yang di Indonesia adalah Pancasila sebagai landasan filosofis dan UUD 1945 sebagai landasan konstitusional. 
Demi mewujudkan kepastian hukum dalam pengelolaan pertambangan, maka tahun 2009, Pemerintah Indonesia menerbitkan UU No. 4 Tahun 2009, dan terkait dengan kontrak karya pertambangan ini, berdasarkan Pasal 169 ditentukan bahwa pada saat undang-undang ini mulai berlaku kontrak karya dan perjanjian karya pengusahaan pertambangan batubara yang telah ada sebelum berlakunya undang-undang ini tetap diberlakukan sampai jangka waktu berakhirnya kontrak/ perjanjian, dan kontrak karya pertambangan antara Pemerintah Indonesia dengan P.T. Freeport Indonesia, akan berakhir pada tahun 2021.

Berdasarkan Pasal 169 huruf b UU No. 4 Tahun 2009, disebutkan pula bahwa ketentuan yang tercantum dalam pasal kontrak karya dan perjanjian karya pengusahaan pertambangan batubara, disesuaikan selambat-lambatnya 1 (satu) tahun sejak undang-undang ini diundangkan kecuali mengenai penerimaan negara. Penyesuaian ini harus segera dilakukan, karena Negara Republik Indonesia yang sesungguhnya mempunyai kedaulatan terhadap bumi, air, ruang angkasa dan kekayaan alam yang terkandung di dalamnya. Hal ini juga sudah dipertegas oleh Mahkamah Konstitusi dalam Putusan Nomor: 36/PUU-X/2012, tentang Pengujian Undang-undang Nomor 22 Tahun 2001 tentang Minyak dan Gas Bumi terhadap Undang-Undang Dasar Negara Republik Indonesia Tahun 1945, yang berpendapat bahwa:

“... negara kehilangan diskresi untuk membuat regulasi bagi kepentingan rakyat yang bertentangan dengan isi kontrak kerja sama, sehingga negara kehilangan kedaulatannya dalam penguasaan sumber daya alam yaitu kedaulatan untuk mengatur Migas yang bertentangan dengan isi kontrak kerja sama. Padahal negara, sebagai representasi rakyat dalam penguasaan sumber daya alam harus memiliki keleluasaan membuat aturan yang membawa manfaat bagi sebesar-besarnya kemakmuran rakyat. Menurut Mahkamah hubungan antara negara dengan swasta dalam pengelolaan sumber daya alam tidak dapat dilakukan dengan hubungan keperdataan, tetapi harus merupakan hubungan yang bersifat publik, yaitu berupa pemberian konsesi atau perizinan yang sepenuhnya di bawah kontrol dan kekuasaan negara. Kontrak keperdataan akan mendegradasi kedaulatan negara atas sumber daya alam ..."

Berdasarkan UU No. 4 Tahun 2009 jo. Putusan Mahkamah Konstitusi Nomor 001-021-022/PUU-I/2003 jo. Putusan Mahkamah Konstitusi Nomor: 36/PUU-X/2012, maka tidak ada lagi alasan yuridis yang membenarkan kontrak 
karya dalam pengelolaan pertambangan oleh Pemerintah dengan P.T. Freeport Indonesia, melainkan hanya melalui mekanisme perizinan. Pengelolaan tersebut juga tidak boleh dilakukan oleh pihak asing, melainkan harus dilakukan sendiri oleh negara melalui Badan Usaha Milik Negara atau Badan Usaha Milik Daerah sebagaimana diatur dalam Undang-undang Nomor 19 Tahun 2003 tentang Badan Usaha Milik Negara.

Kepastian hukum perizinan juga mutlak diperlukan, karena berbagai kasus yang terjadi dalam pengelolaan pertambangan, diasumsikan akibat tumpang tindihnya kewenangan antarinstansi pemerintahan dalam hubungannya dengan penerbitan izin usaha bidang pertambangan, dengan kata lain bahwa terdapat ketidaksinkronan berbagai peraturan perundang-undangan yang berhubungan dengan masalah pengelolaan sumber daya alam, khususnya terkait dengan penerbitan izin usaha bidang pertambangan. Akibat ketidaksinkronan tersebut, tentu saja akan menimbulkan ketidakpastian hukum dalam pengelolaan sumber daya alam bidang pertambangan di Indonesia. ${ }^{41}$ Seperti yang dikatakan Fuller (1971) sebagaimana dikutip oleh Satjipto Rahardjo, bahwa ada 8 (delapan) asas yang harus dipenuhi agar terwujud kepastian hukum, antara tidak boleh adanya peraturan perundang-undangan yang saling bertentangan. ${ }^{42}$ Satya Arinanto juga menyimpulkan bahwa menyangkut substansi atau materi hukum di Indonesia, terdapat permasalahan dalam kerangka politik pembangunan hukum nasional, yakni: ${ }^{43}$

a. terjadinya tumpang tindih peraturan perundang-undangan;

b. inkonsistensi peraturan perundang-undangan; dan

c. implementasi undang-undang yang terhambat oleh peraturan pelaksanaannya.

Sehubungan dengan pokok-pokok pikiran yang diuraikan di atas, maka landasan pemikiran politik hukum pertambangan yang perlu dikembangkan dalam rangka sinkronisasi peraturan perundang-undangan guna efektifitas izin usaha

${ }^{41}$ M. Said Saile, Zulkarnaen Koto, Tengku Erwinsyahbana. Op. Cit. Hlm. 5.

${ }^{42}$ Satjipto Rahardjo. 2006. Hukum dalam Jagat Ketertiban. Jakarta: UKI Press. Hlm. 139.

${ }^{43}$ Satya Arinanto. 2006. Politik Pembangunan Hukum Nasional dalam Era Pasca Reformasi. Jakarta: Universitas Indonesia. Hlm. 24. 
pertambangan harus mempertimbangkan ketentuan yang dimuat dalam UU No. 4 Tahun 2009, yaitu: ${ }^{44}$

a. Pasal 6 ayat (1), menentukan bahwa kewenangan pemerintah dalam pengelolaan pertambangan mineral dan batubara, antara lain:

1) pemberian izin usaha pertambangan, pembinaan, penyelesaian konflik masyarakat, dan pengawasan usaha pertambangan yang berada pada lintas wilayah provinsi dan/atau wilayah laut lebih dari 12 (dua belas) mil dari garis pantai;

2) pemberian izin usaha pertambangan, pembinaan, penyelesaian konflik masyarakat, dan pengawasan usaha pertambangan yang lokasinya berada pada lintas wilayah provinsi dan/atau wilayah laut lebih dari 12 (dua belas) mil dari garis pantai;

3) pemberian izin usaha pertambangan, pembinaan, penyelesaian konflik masyarakat, dan pengawasan usaha pertambangan operasi produksi yang berdampak lingkungan langsung lintas provinsi dan/atau dalam wilayah laut lebih dari 12 (dua belas) mil dari garis pantai;

b. Pasal 7 ayat (1) menentukan bahwa kewenangan Pemerintah Provinsi dalam pengelolaan pertambangan mineral dan batubara, antara lain:

1) pemberian izin usaha pertambangan, pembinaan, penyelesaian konflik masyarakat dan pengawasan usaha pertambangan pada lintas wilayah kabupaten/kota dan/atau wilayah laut 4 (empat) mil sampai dengan 12 (dua belas) mil;

2) pemberian izin usaha pertambangan, pembinaan, penyelesaian konflik masyarakat dan pengawasan usaha pertambangan operasi produksi yang kegiatannya berada pada lintas wilayah kabupaten/kota dan/atau wilayah laut 4 (empat) mil sampai dengan 12 (dua belas) mil;

3) pemberian izin usaha pertambangan, pembinaan, penyelesaian konflik masyarakat dan pengawasan usaha pertambangan yang berdampak lingkungan langsung lintas kabupaten/kota dan/atau wilayah laut 4 (empat) mil sampai dengan 12 (dua belas) mil;

${ }^{44}$ M. Said Saile, Zulkarnaen Koto, Tengku Erwinsyahbana. Op. Cit. Hlm. 43-44 
c. Pasal 8 ayat (1) menentukan bahwa kewenangan Pemerintah Kabupaten/Kota dalam pengelolaan pertambangan mineral dan batubara, antara:

1) pemberian izin usaha pertambangan dan izin pertambangan rakyat, pembinaan, penyelesaian konflik masyarakat, dan pengawasan usaha pertambangan di wilayah kabupaten/kota dan/atau wilayah laut sampai dengan 4 (empat) mil;

2) pemberian izin usaha pertambangan dan izin pertambangan rakyat, pembinaan, penyelesaian konflik masyarakat dan pengawasan usaha pertambangan operasi produksi yang kegiatannya berada di wilayah kabupaten/kota dan/atau wilayah laut sampai dengan 4 (empat) mil;

d. Pasal 37, menentukan bahwa izin usaha pertambangan diberikan oleh:

1) Bupati/Walikota apabila wilayah izin usaha pertambangan berada di dalam satu wilayah kabupaten/kota;

2) Gubernur apabila wilayah izin usaha pertambangan berada pada lintas wilayah kabupaten/kota dalam 1 (satu) provinsi setelah mendapatkan rekomendasi dari Bupati/Walikota setempat sesuai dengan ketentuan peraturan perundangundangan; dan

3) Menteri apabila wilayah izin usaha pertambangan berada pada lintas wilayah provinsi setelah mendapatkan rekomendasi dari Gubernur dan Bupati/Walikota setempat sesuai dengan ketentuan peraturan perundangundangan.

\section{Simpulan dan Saran}

\section{Simpulan}

Berdasarkan uraian di atas, dapat disimpulkan bahwa peran Pemerintah Indonesia sebagai organ negara seharusnya tidak menjadi salah satu pihak dalam kontrak karya dalam eksploitasi dan eksplorasi kekayaan alam di Indonesia, melainkan harus berperan sebagai pengelolanya, karena dikuasai oleh negara tidak berarti bahwa negara menjadi pengusaha, usahawan atau ordernemer. Pengertian dikuasai adalah untuk mengatur dan/atau menyelenggarakan, maka perusahaan tambang yang besar harus dijalankan sebagai usaha negara. 
Adanya kontrak karya pertambangan telah menimbulkan ketidakpastian hukum, karena dalam perspektif kepastian orientasi menuntut agar hukum dikembangkan secara kontinu dan taat asas. Selain itu undang-undang harus saling kait mengkait, harus menunjuk ke satu arah agar masyarakat dapat membuat rencana ke masa depan, begitu pula jangan dibuat undang-undang yang saling bertentangan, dan oleh sebab itu, demi terciptanya kepastian hukum, kontrak karya pertambangan harus diselaraskan dengan nilai-nilai dan cita-cita hukum masyarakat itu sendiri, yang di Indonesia adalah Pancasila sebagai landasan filosofis dan UUD 1945 sebagai landasan konstitusional.

\section{Saran}

Pemerintah sudah semestinya memberikan kesempatan kepada badan usaha yang berbadan hukum Indonesia, koperasi, perseorangan, maupun masyarakat setempat untuk melakukan pengusahaan pertambangan berdasarkan izin yang sejalan dengan otonomi daerah, yang diberikan oleh Pemerintah dan/atau Pemerintah Daerah sesuai dengan kewenangannya masing-masing.

Pancasila harus dijadikan landasan filosofis/idologis dalam melaksanakan singkronisasi peraturan perundang-undangan guna efektifitas izin usaha pertambangan. Selain itu, UUD 1945 juga harus dijadikan landasan konstitusional, karena berdasarkan asas hak menguasai negara, sumber daya alam hanya dapat dipergunakan untuk sebesar-besar kemakmuran rakyat, sesuai amanat Pasal 33 UUD 1945. 


\section{DAFTAR PUSTAKA}

\section{Buku/Kamus:}

Achmad Ali. 2009. Menguak Teori Hukum (Legal Theory) dan Teori Peradilan (Judicial Prudence) Termasuk Interpretasi Undang-undang (Legisprudence). Edisi Pertama. Cetakan Kedua. Jakarta: Kencana.

Astim Riyanto. 2002. Filsafat Hukum. Bandung: Yapemdo.

Bagir Manan. 1995. Pertumbuhan dan Perkembangan Konstitusi Suatu Negara. Bandung: Mandar Maju.

BPHN. 1997/1998. Penyusunan Kamus Hukum Umum Bahasa Belanda-Bahasa Indonesia. Jakarta: BPHN-Departemen Kehakiman dan HAM RI.

Budiono Kusumohamidjojo. 1999. Ketertiban yang Adil (Problematik Fisafat Hukum). Jakarta: Grasindo.

Darji Darmodiharjo dan Shidarta. 1996. Penjabaran Nilai-nilai Pancasila dalam Sistem Hukum Indonesia. Jakarta: Rajawali Pers.

Franz Magnis Suseno. 2001. Etika Politik. Jakarta: Gramedia Pustaka Utama.

Harahap, Krisna. 2003. HAM dan Upaya Penegakannya di Indonesia. Bandung: Grafitri Budi Utami.

Hestu Cipto Handoyo, B. 2003. Hukum Tata Negara, Kewarganegaraan \& Hak Asasi Manusia, Memahami Proses Konsolidasi Sistem Demokrasi di Indonesia. Cetakan Pertama. Yogyakarta: Universitas Atma Jaya.

Jimly Asshiddiqie dan M. Ali Safa'at. 2006. Teori Hans Kelsen tentang Hukum. Cetakan Pertama. Jakarta: Sekretariat Jenderal \& Kepaniteraan Mahkamah Konstitusi RI.

Johnny Ibrahim. 2006. Teori dan Metodologi Penelitian Hukum Normatif. Cetakan Kedua. Malang: Bayumedia Publishing.

Mochtar Kusumaatmadja (Editor: R. Otje Salman S. dan Edi Damian). 2006. Konsep-konsep Hukum dalam Pembangunan (Kumpulan Karya Tulis). Cetakan Kedua. Bandung: Alumni.

Mohammad Hatta. 1977. Penjabaran Pasal 33 Undang-Undang Dasar 1945. Jakarta: Mutiara.

Muhammad Bakri. 2007. Hak Menguasai Tanah oleh Negara (Paradigma Baru untuk Reformasi Agraria). Yogyakarta: Citra Media.

Muhammad Yamin. 1954. Proklamasi dan Konstitusi. Jakarta: Djembatan.

Notonagoro. t.t. "Pembukaan Undang Undang Dasar 1945 (Pokok Kaidah Fundamentil Negara Indonesia" dalam Pancasila Dasar Falsafah Negara. Cetakan Keempat. Jakarta: Pantjuran Tudjuh. 
Pusat Bahasa Departemen Pendidikan Nasional. 2002. Kamus Besar Bahasa Indonesia. Jakarta: Balai Pustaka.

Salim HS dan Erlies Septiana Nurbaini. 2013. Penerapan Teori Hukum pada Penelitian Tesis dan Disertasi. Jakarta: RajaGrafindo Persada.

Satjipto Rahardjo. 2006. Hukum dalam Jagat Ketertiban. Jakarta: UKI Press.

Satya Arinanto. 2006. Politik Pembangunan Hukum Nasional dalam Era Pasca Reformasi. Jakarta: Universitas Indonesia.

Soerjono Soekanto dan Sri Mamudji. Penelitian Hukum Normatif, Suatu Tinjauan Singkat. Cetakan Keenam. Jakarta: RadaGrafindo Persada. 2003.

Soerjono Soekanto. 2012. Pengantar Penelitian Hukum. Cetakan Ketiga. Jakarta: UI-Press.

Subekti, R. dan R. Tjitrosudibio. 2009. Kitab Undang-undang Hukum Perdata (Burgerlijk Wetboek). Jakarta: Balai Pustaka.

Sudikno Mertokusumo. 1993. Bab-bab tentang Penemuan Hukum. Bandung: Citra Aditya Bakti.

\section{Disertasi:}

Hamid S. Attamimi, A. 1990. "Peranan Keputusan Presiden Republik Indonesia dalam Penyelenggaraan Pemerintahan Negara: Suatu Studi Analisis Mengenai Keputusan Presiden yang Berfungsi Pengaturan dalam Kurun Waktu Pelita I-Pelita IV", Disertasi, Jakarta: Fakultas Pascasarjana Universitas Indonesia.

Tengku Erwinsyahbana. 2012. "Kajian atas Kepastian Hukum Perkawinan Antar Agama Dikaitkan dengan Sistem Hukum Perkawinan Indonesia dalam Perspektif Pembangunan Hukum Keluarga Nasional”. Disertasi. Bandung: Fakultas Hukum Program Doktor Ilmu Hukum Pascasarjana Universitas Padjadjaran.

\section{Situs Internet:}

Agustin Tri Setiyani, Ery Agus Priyono, Agung Basuki. 2013. "Tinjauan Yuridis Penerapan Asas Proporsionalitas p Renegosiasi Kontrak Karya antara Pemerintah Indonesia dengan P.T. Freeport Indonesia”. Diponegoro Law Review. Volume 1. Nomor 2. Dari http://ejournal-s1.undip.ac.id. Diakses tanggal 19 Maret 2017.

Arif Hidayat. "Kepastian Hukum Harus Sejalan dengan Rasa Keadilan" dalam Antara News, http://www.antaranews.com. Diakses tanggal 12 Maret 2017. 
Asdar Kadir. "Hak Menguasai Negara Atas Tanah Sebagai Dasar Perampasan Hak Perseorangan Atas Tanah (Tinjauan terhadap Pengadaan Hak Atas Tanah Demi Kepentingan Umum)", http://asdarkadir.blogspot.com. Diakses tanggal 12 Maret 2017.

Jimly Ashiddiqie. "Keadilan, Kepastian Hukum dan Keteraturan," http://www. suarakarya-online.com. Diakses tanggal 12 Maret 2017.

Malik Ibrahim. Asas Kepastian Hukum (Rule of Law Principle). http://alikibe. blogspot.com. Diakses tanggal 12 Maret 2017.

Pan Mohamad Faiz. "Penafsiran Konsep Penguasaan Negara Berdasarkan Pasal 33 UUD 1945 dan Putusan Mahkamah Konstitusi”. http://dosen.narotama. ac.id. Diakses tanggal 12 Maret 2017.

Said Saile, M., Zulkarnaen Koto, Tengku Erwinsyahbana. 2012. "Sinkronisasi Peraturan Perundang-undangan Guna Efektivitas Penerbitan Izin Usaha Bidang Pertambangan Dalam Rangka Ketahanan Nasional". Jakarta: Lembaga Ketahanan Nasional Republik Indonesia. Dari https://erwin6768. blogspot.co.id. Diakses tanggal 20 Maret 2017.

Yance Arizona. “Apa Itu Kepastian Hukum”. http://yancearizona.wordpress.com. Diakses tanggal 12 Maret 2017.

\section{Peraturan Perundang-undangan:}

Republik Indonesia, Undang Undang Dasar Tahun 1945.

Republik Indonesia, Undang-undang Nomor 5 Tahun 1960 tentang Peraturan Dasar Pokok-pokok Agraria.

Republik Indonesia, Undang-undang Nomor 17 Tahun 2007 tentang Rencana Pembangunan Jangka Panjang Nasional Tahun 2005-2025.

Republik Indonesia, Undang Undang Nomor 25 Tahun 2007 tentang Penanaman Modal.

Republik Indonesia, Undang-undang Nomor 4 Tahun 2009 tentang Pertambangan Mineral dan Batubara.

Republik Indonesia, Mahkamah Konstitusi Putusan Nomor: 001-021-022/PUUI/2003, tentang Pengujian Undang-undang Nomor 20 Tahun 2002 tentang Ketenagalistrikan terhadap Undang Undang Dasar Negara Republik Indonesia Tahun 1945.

Republik Indonesia, Mahkamah Konstitusi Putusan Nomor: 36/PUU-X/2012, tentang Pengujian Undang-undang Nomor 22 Tahun 2001 tentang Minyak dan Gas Bumi terhadap Undang Undang Dasar Negara Republik Indonesia Tahun 1945. 


\section{PENULIS}

1. Nama : Dr. Tengku Erwinsyahbana, S.H., M.Hum

Pekerjaan : Dosen

Institusi : Program Magister Kenotariatan Universitas Muhammadiyah Sumatera Utara

Alamat : Jalan Denai No. 217, Medan-Sumatera Utara

Email : erwin6768@gmail.com

No. HP : 081397622420

2. Nama : Vivi Lia Falini Tanjung, S.H.

Pekerjaan : -

Institusi : Program Magister Kenotariatan Universitas Muhammadiyah Sumatera Utara

Alamat : Jalan Denai No. 217, Medan-Sumatera Utara

Email : tanjungn10@gmail.com

No. HP ： 081263008181 